\title{
PENGALAMAN KEPALA RUANGAN DALAM MENGELOLA RUANGAN YANG MERAWAT PASIEN COVID 19
}

\author{
Brension Relly, Yati Afiyanti, Muhammad Syafwani \\ ${ }^{1 \& 3}$ Universitas Muhammadiyah Banjarmasin, ${ }^{2}$ Universitas Indonesia (UI) Depok Jawa \\ Barat, Indonesia \\ Email: brension@gmail.com, yatiafiyanti@yahoo.com, m.syafwanibjm@gmail.com
}

\begin{abstract}
Abstrak
Wabah Covid 19 baru-baru ini telah berkembang dari keadaan darurat kesehatan masyarakat menjadi pandemi global utama. Ketika pandemi Covid 19 muncul sebagai krisis perawatan kesehatan global, para ilmuwan di seluruh dunia secara aktif mengembangkan intervensi profilaksis dan terapeutik. Pada masa pandemi manajemen strategi kepala ruangan memegang peranan yang sangat penting. Strategi yang diambil harus mampu beradaptasi dengan sangat cepat, baik level organisasi, korporat, unit bisnis, atau level operasional. pengelolaan Man, Money, Material, Machines, dan Method dalam unsur manajamen menjadi hal yang krusial untuk di kelola oleh seorang kepala ruangan Penelitian ini bertujuan untuk mengekplorasi secara mendalam Pengalaman Kepala Ruangan dalam mengelola Ruangan Yang Merawat Pasien Covid 19. Metode penelitian dengan Data kualitatif diperoleh melalui indepth interview pada 10 orang partisipan Rumah Sakit A dan B di Palangka Raya Kalimantan tengah dengan mengunakan metode kualitatif dengan teknik purposive sampling. Hasil penelitian menemukan 6 tema utama yaitu (1).Pengelolaan Sumber Daya Manausia Perawat, (2).Pengelolaan Keuangan, (3). ketersedian bahan habis pakai, (4).Kesiapan alat medis, (5) Metode pengelolaan ruangan, (6).evaluasi manajemen pengelolaan sumber daya manusia, keuangan, sarana, ketersedian alat, metode tata kelola ruangan. Hasil penelitian ini menyimpulkan bahwa pengelolaan dan evaluasi kepala ruangan selama pandemic Covid 19 perlu pengelolaan sumber daya manusia, keuangan, ketersediaan bahan habis pakai, alat dan metode tata kelola ruangan menjadi perhatian khusus para manajer rumah sakit yang melakukan pemberiaan layanan kesehatan kepada pasien Covid 19.
\end{abstract}

Kata kunci: Covid 19; Pengalaman Kepala Ruangan; Pengelolaan ruangan.

\section{Abstract}

The recent Covid 19 outbreak has grown from a public health emergency to a major global pandemic. As the Covid 19 pandemic emerged as a global health care crisis, scientists around the world were actively developing prophylactic and therapeutic interventions. During the pandemic, the management of the chief strategist played a very important role. The strategy taken must be able to adapt very quickly, whether organizational, corporate, business unit, or operational level. The management of Man, Money, Materials, Machines, and Methods in the element of management becomes crucial to be managed by a head of the room This research aims to explore in depth the Experience of the Head of Room in managing

$\begin{array}{ll}\text { How to cite: } & \text { Relly, B., Afiyanti,Y., Syafwani, M., (2022) Pengalaman Kepala Ruangan dalam Mengelola Ruangan } \\ & \text { yang Merawat Pasien Covid 19, Syntax Idea, 4(1), https://doi.org/10.36418/syntax-idea.v4i1.1717 } \\ \text { E-ISSN: } & \text { 2684-883X } \\ \text { Published by: } & \text { Ridwan Institute }\end{array}$


the Room That Cares for Covid 19 Patients. Research methods with qualitative data were obtained through indepth interviews on 10 participants of Hospital A and $B$ in Palangka Raya central Kalimantan using qualitative methods with purposive sampling techniques. The results of the study found 6 main themes, namely (1). Management of Resources of Manausia Nurse, (2). Financial Management, (3). availability of consumables, (4). Readiness of medical devices, (5) Room management methods, (6). evaluation of management of human resources management, finance, facilities, availability of tools, room governance methods. The results of this study concluded that the management and evaluation of the head of the room during the Covid 19 pandemic needs the management of human resources, finance, availability of consumables, tools and methods of room governance to be of particular concern to hospital managers who provide health services to Covid 19 patients.

Keywords: Covid 19; Head of Room Experience; Room management

\section{Received: 2021-12-22; Accepted: 2022-01-05; Published: 2022-01-20}

\section{Pendahuluan}

Wabah Covid 19 baru-baru ini telah berkembang dari keadaan darurat kesehatan masyarakat menjadi pandemi global utama. Covid 19 disebabkan oleh coronavirus SARS-CoV-2 (Alhazzani et al., 2020). Pada 8 Agustus 2020, terdapat 19.481 .330 kasus terkonfirmasi dan 723.599 kematian di seluruh dunia dengan 188 negara terdampak (Corona Virus Resourrce Center, 2020). Ketika pandemi Covid 19 muncul sebagai krisis perawatan kesehatan global, para ilmuwan di seluruh dunia secara aktif mengembangkan intervensi profilaksis dan terapeutik.

Langkah-langkah untuk peningkatan kesehatan telah diterapkan secara darurat oleh sebagian besar negara yang terkena dampak, membatasi kebebasan pribadi (karantina yang diberlakukan, isolasi wajib terhadap kasus-kasus yang dicuriga, didiagnosis, pelacakan kontak dan pemantauan) memaksakan restrukturisasi sistem kesehatan, termasuk relokasi yang cepat dari para profesional kesehatan memberikan bantuan perawatan ke dalam unit rumah sakit Covid 19 yang direstrukturisasi atau ke kota-kota yang berbeda (Sullivan \& Phillips, 2020).

Ketidakpastian umum, ancaman kesehatan individu, serta tindakan karantina dapat memperburuk kondisi yang sudah ada sebelumnya seperti depresi, kecemasan, dan gangguan stres pasca-trauma. Selain itu, risiko penularan penyakit dapat meningkatkan ketakutan kontaminasi pada pasien dengan gangguan obsesif-kompulsif dan hipokondria, atau individu dengan riwayat ide paranoid.

Harus diakui bahwa banyak petugas kesehatan berada di garis depan wabah koronavirus. Perlu memperhatikan profesional kesehatan yang bekerja di unit gawat darurat atau perawatan intensif dengan beban kerja yang lebih berat dan lebih stres daripada biasanya karena yang dirawat adalah pasien Covid 19 (Ross, Niebling, \& Heckert, 1999), (Seale et al., 2012), (Li et al., 2020), (Li et al., 2020). 
Tenaga profesional kesehatan akan mengalami kondisi kejiwaan yang lebih berat, terjadi pemisahan dari keluarga, situasi yang tidak biasa, peningkatan paparan terhadap virus corona, ketakutan penularan, dan perasaan gagal dalam menghadapi prognosis yang buruk dan sarana teknis yang tidak memadai untuk membantu pasien. Bagi petugas layanan kesehatan, akan sulit untuk tetap sehat secara mental dalam situasi yang berkembang pesat ini, dan mengurangi risiko depresi, kecemasan, atau kelelahan. Selain itu, mereka secara khusus menghadapi risiko yang meningkat untuk 'cedera moral' ketika berhadapan dengan tantangan etis pandemi coronavirus, seperti bekerja dalam kondisi dengan sumber daya yang tidak mencukupi/memadai, situasi triase, perawatan paliatif yang tidak memadai dan tidak mampu mendukung keluarga pasien terminal. Beberapa sumber daya tersedia untuk petugas kesehatan dan beberapa strategi yang direkomendasikan, meliputi dukungan tim, pemantauan stres, mengurus diri sendiri, beristirahat secara teratur, dan berhubungan dengan orang lain.

Berdasarkan (https://coronavirus.jhu.edu/map.html, 2021) mencatat penambahan kasus konfirmasi Covid 19 tanggal 18 Juni 2021 di Dunia sebanyak 177,108,695 kasus, kasus meninggal 3,840,223 kematian (CFR 2,2\%) di 222 negara terjangkit dan 149 negara tranmisi komunitas. Sedangkan di Indonesia dari data Kemenkes RI tanggal 18 Juni 2021 ada 1.963.266 orang terkonfirmasi Covid 19 dan ada 54.043 kematian (CFR $2,8 \%$ ), pasien yang dilaporkan sembuh ada 1.779.127. Data di Kalimantan Tengah pada tanggal 20 Juni 2021 jumlah konfirmasi Covid 19 ada 24.303 kasus, jumlah meninggal ada 648 orang (CFR 2,7\%), pasien yang sembuh dari Covid 19 ada 22.411 orang. Berdasarkan data di Wilayah Palangka Raya, kasus konfirmasi Covid 19 dilaporkan 6943 kasus, yang meninggal ada 211 kematian, yang dilaporkan sembuh ada 6331 orang. Berdasarkan data yang didapatkan dari Tim Data Satgas Penanggulangan Covid 19 dari bulan April 2020 sampai dengan awal bulan Juni 2021 terdapat 63 kasus konfirmasi Covid 19 perawat yang terkonfirmasi Covid 19.

Krisis kesehatan berskala besar, memicu restrukturisasi dan reorganisasi pemberian layanan kesehatan untuk mendukung layanan darurat, unit perawatan intensif medis dan unit perawatan berkelanjutan. Para profesional kesehatan mengerahkan semua sumber dayanya untuk memberikan bantuan darurat dalam iklim ketidakpastian yang umum. Kekhawatiran tentang kesehatan mental, penyesuaian psikologis, dan pemulihan pekerja perawatan kesehatan yang merawat pasien dengan Covid 19 mulai muncul. (Zeng, Sun, Yang, Shen, \& Liu, 2016) dalam penelitiannya menyatakan karakteristik penyakit dari pandemi Covid 19, meningkatkan suasana kewaspadaan dan ketidakpastian umum, terutama di kalangan profesional kesehatan, karena berbagai penyebab seperti penyebaran dan penularan cepat Covid 19, keparahan gejala yang ditimbulkannya dalam suatu segmen, orang yang terinfeksi, kurangnya pengetahuan tentang penyakit, dan kematian di kalangan profesional kesehatan.

Dalam situasi ini kepala ruangan dalam hal ini memiliki sebuah peran penting yang harus di jalaninya. (Kurniadi, 2013) menyatakan dalam ruang perawatan, kepala ruangan adalah seorang yang memiliki kewajiban untuk melakukan fungsi manajemen yang terdiri dari fungsi perencanaan, fungsi pengorganisasian, fungsi penggerakan, dan 
fungsi pengawasan. Sebagai pengelolapelayanan keperawatan seorang pemimpin, seorang kepala ruangan mampu sebagai entrepreneur, decision maker, dan manajemen risk Mengutip dari tatnan ruangan pelayanan infeksi di rumah pada masa pandemi kepala ruangan memiliki peran dalam mengelola 7 aspek dimasa pandemi : (1) Alur Proses Kegiatan Pelayanan, (2) Zoning, Fungsi Ruang dan Tata ruang/Lay-out,

Bentuk, Karakteristik \& Komposisi Bangunan, (4) JenisKonstruksi Bangunan dan Prasarana (5) Program, Persyaratan \& Hubungan antar Ruangan, (6) Utilitas dan Fasilitas Penunjang, (7) Ketersediaan dan Kualitas Alkes dan APD.

Pelaksanaan fungsi manajemen oleh kepala ruangan adalah sistem yang memudahkan dalam memberikan asuhan keperawatan pada klien. Kepala ruangan harus dapat melaksanakan fungsi manjemen yang baik di ruangan dalam pemberian pelayanan keperawatan. Pelaksanaan fungsi manjemen yang tidak optimal dapat berdampak bagi pasien. Hambatan dalam pelaksanaan fungsi manajemen yakni hambatan yang berasal dari personal perawat dan hambatan dari kondisi lingkungan di ruang rawat inap. (Winasih, Nursalam, \& Kurniawati, 2015) Pelaksanaan fungsi manajeman pada masa pandemi juga masih mengalami berbagai masalah mulai beratnya beban kerja perawat/tidak sesuaian jumlah perawat dengan pasien yang di rawat, pelaksanaan standar PPI rumah sakit yang belum optimal dimana masih ada laporan penularan ke petugas kesehatan baik dokter maupun perawat.

Berdasarkan hasil wawancara informal dengan kepala ruangan Covid 19 diketahui bahwa selama melaksanakan fungsinya sebagai kepala ruangan selama masa pandemi ini mendapatkan banyak perubahan dan tantangan baru, dimana di saat pandemi ini semua kepala ruangan mengatakan kekurangan perawat karena jumlah pasien Covid 19 yang terus meningkat, dan juga kebutuhan APD yang meningkat serta perlengkapan perawatan seperti oksigen, ventilator dan obat obatan bagi pasien dengan Covid 19. Hasil wawancara juga menunjukkan dimasa pendemi ini kepala ruangan juga harus menyiapkan kebutuhan gizi pendukung bagi para perawat pelaksana yang bertugas, yang sebelum dimasa seperti biasa tidak menjadi hal yang sangat urgen.

Kepala ruang harus mampu menjalankan fungsi manajemen sehingga tujuan organisasi dapat tercapai. Dalam mengaktifkan kembali sebuah sistem, tentu tidak terlepas dari unsur-unsur manajemen yang harus lebih diperhatikan, agar tujuan dapat dicapai dengan optimal. Unsur-unsur tersebut dikenal dengan istilah 5M (man, money, material, machines dan method). Kelima unsur tersebut merupakan elemen dasar dalam melakukan fungsi sebuah sistem. Man merujuk pada sumber daya manusia yang dimiliki oleh organisasi. Dalam manajemen faktor manusia adalah yang paling menetukan. Manusia yang membuat tujuan dan manusia pula yang melakukan proses untuk mencapai tujuan. Tanpa ada manusia tidak ada proses kerja, sebab pada dasarnya manusia adalah makhluk kerja. Oleh karena itu, manajemen timbul karena adanya orang-orang yang bekerja sama untuk mencapai tujuan. Money merupakan salah satu unsur yang tidak dapat diabaikan. Uang merupakan alat tukar menukar yang memiliki nilai guna tinggi. Besar kecilnya hasil kegiatan dapat diukur dari jumlah uang yang beredar dalam perusahaan. oleh karena itu uang merupakan alat yang penting untuk 
mencapai tujuan karena segala sesuatu harus diperhintungkan secara rasional. Hal ini akan berhubungan dengan berapa uang yang harus disediakan untuk membiayai gaji tenaga kerja, alat-alat yang dibutuhkan dan harus dibeli serta berapa hasil yang akan dicapai dari suatu organisasi. Materials terdiri dari bahan setengah jadi dan bahan jadi. Pada masa pandemi manajemen strategi memegang peranan yang sangat penting. Strategi yang diambil harus mampu beradaptasi dengan sangat cepat, baik level organisasi, korporat, unit bisnis, atau level operasional. Man, Money, Materials, Machines, Method dalam unsur majamen manjadi hal yang krusial untuk di kelola oleh seorang kepala ruangan.

Man (manusia) pada masa pandemi perlu dilakukan pengaturan jadwal jaga dan penghitungan jumlah perawat dan pasien seuai pedoman rumah sakit. Money kebutuhan APD yang di perukan oleh tenaga kesehatan diruangan perawatan isolasi, mereka juga memerlukan asupan gizi yang maksimal selama menjalankan tugas melakukan perawatan. Material terkait dengan mempersiapkan Standar Operasional Prosedur (SOP) perawatan pasien dengan Covid 19. Dan berbagai pelatihan yang menunjang proses pelaksanaan perawatan. Machines dimasa pandemi merujuk dari penyediaan alat kesehatan untuk fasilitas pelayanan kesehatan sebagai tempat karantina dan isolasi Covid 19. Unsur yang terakhir adalah method mempersiapkan manejemen layanan yang sesuai standar protokol kesehatan nasional dan mendukung produktivitas kerja namun tetap memprioritaskan kesehatan dan keselamatan dengan pencegahan dan pengendalian transmisi Covid 19 sehingga dapat memberikan perlindungan terhadap keselamatan pasien, masyarakat, lingkungan Rumah Sakit dan sumber daya manusia di Rumah Sakit (Panduan Teknis Pelayanan di Rumah Sakit pada masa Kebiasaan Baru dari Kemenkes RI tahun 2020).

Menurut (Coulter, 2010) menyatakan bahwa, manajemen melibatkan koordinasi dan pengawasan penyelesaian yang efisien dan efektif dari aktivitas kerja lainnya. Dalam melaksanakan tugas dan fungsi perawat dengan efektif dan efisien tentunya banyak faktor yang mempengaruhi, salah satunya adalah stres dan kecemasan kerja terutama di masa pancemi Covid 19. Perspektif NEJM (New England Journal of Medicine), Pfefferbaum dan Utara menjelaskan bahwa sistem perawatan kesehatan perlu menangani tekanan pada penyedia individu dan operasi umum dengan memantau reaksi dan kinerja, mengubah tugas dan jadwal, memodifikasi ekspektasi, dan menciptakan mekanisme untuk menawarkan dukungan psikososial sesuai kebutuhan (Pfefferbaum \& North, 2020).

Pemicu stres, akibat Covid 19, pada tingkat individu, tim, organisasi dan kehidupan kerja, memiliki dampak dalam tim. Ketika pemimpin dan manajer tim tidak bereaksi secara efektif, hal itu dapat mengakibatkan kerja tim yang buruk yang dapat berdampak negatif berdampak pada kualitas perawatan dan keselamatan pasien (Sullivan \& Phillips, 2020).

Menurut Scotti tannenbaum, Allison M traylor, \& Eduardo Salas Tahun 2020 ada 6 risiko yang dapat dialami oleh kepalaruangan selama menjalankan manajemen kepala ruangan yaitu: (1) Ketidakpastian atau keraguan bahwa tim dapat berhasil, (2) 
Ketidakpastian atau keraguan bahwa tim dapat berhasil, (3) Manifestasi perpecahan, (4) Pemantauan, kewaspadaan, yang tidak memadai, (5) Gagal untuk mengajukan pertanyaan atau mengakui kekhawatiran, (6) Terlalu fokus pada diri sendiri, (7) Ketahanan tim yang rendah.

Pernyataan tersebut diatas menggambarkan seorang kepala ruangan dalam menjalankan tugasnya di masa pandemi bisa mengalami: Ketidakpastian atau keraguan tim itu bisa berhasil; kolektif kemanjuran yang buruk, Persaingan atau tidak konsistennya mental model; penyempitan perhatian, Manifestasi perpecahan, kesalahan garis; silo, Tidak memadai dalam pemantauan, kewaspadaan, cadangan; penyempitan perhatian; keamanan psikologis rendah, Ketidaknyamanan saat berbicara; kurangnya keamanan psikologis; gagal untuk bertanya atau mengakui kekhawatiran, Mempersempit perhatian; terlalu fokus pada diri sendiri; mengurangi kewaspadaan, Kemunduran yang berdampak buruk pada kesiapan untuk menjalankan tugas selanjutnya; low team resilience. Keadaan ini dapat bedampak pada pelaksanaan fungsi kepala ruangan sebagai lower manajer dalam keperawatan yang di tuntut harus mampu menjalankan fungsi manajemen sehingga tujuan organisasi dapat tercapai.

Manajemen keperawatan merupakan rangkaian fungsi dan aktivitas yang secara simultan saling berhubungan dalam menyelesaikan pekerjaan melalui anggota staf keperawatan untuk meningkatkan efektifitas dan efisiensi pelayanan keperawatan yang berkualitas (Marquis \& Huston, 2010). Kualitas pemberian asuhan keperawatan bagi pasien dapat dilihat dari pemberian asuhan keperawatan yang aman. Tujuan pelayanan keperawatan yang berkualitas dapat tercapai apabila manajer keperawatan mampu melaksanakan fungsi manajemen dengan baik.

Berdasarkan gambaran fenomena ini peneliti akan mengeksplorasi pengalaman kepala ruangan dalam melaksanakan fungsi mengelola ruangan selama masa pandemik Penelitian ini bertujuan untuk mengeksplorasi pengalaman kepala ruangan dalam melaksanakan pengelolaan Man, Money, Material, Machines, dan Method selama masa pandemik.

\section{Metode Penelitian}

Penelitian ini menggunakan metode penelitian kualitatif dengan pendekatan fenomenologi, yang bertujuan untuk mengidentifikasi dan Mengeksplorasi pengalaman pengalaman kepala ruangan dalam melaksanakan fungsi mengelola ruangan selama masa pandemik. Ada 10 (Sepuluh) partisipan yang terlibat pada penelitian ini. Sepuluh responden ini adalah seluruh Kepala Ruangan Covid 19 yang berada di Rumah sakit A dan B.

\section{Hasil dan Pembahasan}

Partisipan dalam penelitian ini adalah kepala ruangan Covid 19 dalam mengelola ruangan selama pandemi Covid 19. Sebanyak 10 (sepuluh) orang perawat kepala ruangan berpartisipasi dalam penelitian ini. 
Partisipan laki-laki sebanyak 2 orang dan partisipan perempuan 8 orang. Usia partisipan bervariasi dengan usia termuda 35 tahun dan tertua 52 tahun. Status pekerjaan partisipan 9 orang PNS dan 1 orang tenaga kontrak. Latar belakang pendidikan partisipan yaitu pendidikan Ners 8 dan D3 2 orang.

Hasil penelitian mengidentifikasi pengalaman pengalaman kepala ruangan dalam melaksanakan fungsi mengelola ruangan selama masa pandemik sebanyak 6 tema sebagai berikut:

1. Pengelolaan SDM perawat

Pandemi COVID 19ini menjadi fokus perhatian baik pemerintah, swasta untuk mengurangi penyebaran Covid 19 dan penanganan Covid 19 ini. Sebagai upaya dari pemerintah dalam menangani Covid 19, pemerintah melakukan rekruitmen relawan penanganan Covid 19. Hal ini bertujuan untuk membantu garda terdepan dalam upaya menangani Covid 19 akibat dari kurangnya jumlah sumber daya manusia yang ada. Hal ini dilakukan baik ditingkat pusat maupupun provinsi yang dilakukan oleh kepala pemerintah ataupun gugus tugas penanganan Covid 19. Dalam rekruitmen kerelawanan biasanya dibagi dalam dua kelompok yaitu relawan medis dan relawan non medis. Sumber daya manusia merupakan elemen yang paling penting dalam suatu organisasi dibandingkan dengan elemen lain seperti modal, teknologi dan uang sebab manusia itu sendiri yang mengendalikan elemen lainnya. Sumber daya manusia yang melimpah menjadikan tidak adanya kekhawatiran bagi organisasi pelayanan kesehatan dalam melaksanakan rekrutmen relawan saat pandemi Covid 19 untuk membantu memberikan pelayanan di tengah pandemi Covid 19. Selain itu, kegiatan pengembangan yang dilakukan untuk kerelawanan dapat memperoleh tambahan keterampilan dan pengetahuan baru yang bermanfaat bagi pelaksanaan setiap kegiatan relawan dimasa pandemi Covid 19. Kompetensi merupakan suatu karakteristik dasar dari seseorang yang memungkinkan orang tersebut memberikan kinerja unggul dalam pekerjaan, peran, atau situasi tertentu. Kompetensi perawat menjadi penentu kualitas pelayanan yang diberikan. kompetensi terdiri dari pengetahuan (knowledge), kemampuan/keterampilan (skill), konsep diri (self consepts), motivasi (motives), serta sifat (traits) dapat disesuaikan dengan bidang pekerjaan yang dibutuhkan oleh rumah sakit, sehingga dapat menghasilkan kinerja pegawai yang tinggi. Hal ini menunjukkan bahwa kompetensi menjadi sangat penting dan berguna bagi perawat dalam meningkatkan kinerjanya.

Senada dengan yang diungkapkan Bernardin dan Russell dalam Rahmanita 2020 menjelaskan bahwa kinerja merupakan hasil kerja seorang karyawan pada periode tertentu. Kinerja merupakan hasil kerja keseluruhan dari kualitas, kuantitas, kedisiplinan, dan kerja sama karyawan dalam grup di suatu organisasi. Kinerja dari karyawan dapat berbeda, tergantung pada deskripsi pekerjaan masing-masing karyawan perawat memiliki deskripsi kerja untuk mendorong, mengangkat, mengangkut dan tindakan yang berhubugan dengan keterampilan dan keahlian klafikasi pendidikan dan pelatihan ini juga sesuai dengan hasil penelitian ini yaitu dimana beberapa partisipan mengatakan untuk SDM kita bedakan menjadi dua yaitu 
organik dan non organik dan untuk pembagian jadwal di sesuaikan dengan klasifikasi Pendidikan.

“...Kalau untuk SDM nya saat ini ada 2 jenis yang pertama Organik dan yang kedua itu relawan. Kalau untuk organik, PNS sudah tenaga kontrak otomatis mereka sudah ada"

"...Ya, pada prinsipnya tetap yang bertanggung jawab adalah perawat organiknya atau ASN nya

“...terus terang waktu pertama kali Covid 19 ya, eee dimana yang masuk itu adalah relawan. Relawan dimana mereka harus belajar, yang pertama yang tidak bisa ee melakukan tindakan jadi kita yang organik yang akan mendampingi mereka.

Senada dengan yang diungkapkan Khofiyya Fathimah Az Zahra F 2020 Perekrutan SDM atau relawan pada masa pandemi Covid 19 ini sangat penting dilakukan melihat bagaimana situasi dan kondisi sekarang dimana dengan sumber daya manusia yang melimpah diharapkan dapat membantu menanggulangi Covid 19. Hal tersebut tentu akan membantu kinerja staff dalam suatu lembaga pelayanan sosial ketika memiliki banyak tugas ini juga sesuai dengan hasil penelitian ini yaitu dimana beberapa partisipan mengatakan untuk membantu merawat pasien Covid 19 yang banyak, mereka melakukan perekrutan relawan Covid 19 dan meminta kepada manajemen yang diusulkan dari ruangan dan meminta solusi kepada manajemen keperawatan terkait kekurangan relawan Covid 19.

“...saya akan minta tambahan tenaga langsung, biasanya akan ada rekrut relawan atau mutasi perawat keruangan langsung”.

“...Nah terus terang kemarin niatnya minta tolong dengan pihak manajemen dimana solusi nya akhirnya dari pihak manajemen merekrut lagi yang tenaga relawan, dimana tenaga relawannya rata-rata yang memang baru.".

Menurut (Jum \& Dia, 2021), beberapa isu terkait SDM perawat pada masa pandemi Covid 19 bahwa perawat sangat dekat dengan pasien, tidak hanya membantu terkait membantu kebutuhan sehari hari terkait juga monitoring kondisi pasien, pada era Covid 19 terjadi perubahan besar terkait tata kelola SDM dan APD serta pelayanan kesehatan lainya sehingga manajer perlu menguasai perubahan tersebut dari segi pelayanan keperawatan, ketenagan serta flexsibelitas dimana beberapa partisipan dalam penelitian ini mengatakan pelatihan pengunaan APD dan melakukan tata kelola SDM dengan membagi setiap jam dinas merata dan seimbang sehingga rekrutmen perawat juga harus sesuai pendidikan Ners dan D3 dan harus dengan permintaan ruangan dan bidang keperawatan dan di kelola.

“...kalo pelatihan ppi dasar sebelum masuk ruangan langsung diberikan,minimal tentang pemasangan baju apd dan situasi pasien Covid 19

“...Waktu pertama kali diajarkan dulu,diperkenalkan dulu tata ruangnya seperti apa,tata dasar komuniasi dulu.

Beberapa partisipan pada penelitian ini juga mengatakan saat melakukan rekrutmen perawat untuk penambahan SDM perawat Covid 19 dilakukan pembagian 
porsi tingkat pendidikan Ners dan D3 keperawatan sesuai dengan kualifikasi keahlian tingkat pendidikan mereka dan beberapa partisipan juga mengatakan kalau dalam berkerja dinas sore dan malam mereka sudah di atur sesuai pembagian jaga antara ners dan D3 keperawatan harus seimbang terkait kebutuhan dilapangan untuk merawat pasien dengan Covid 19 di perlukan tenaga yang seimbang.

„,...kalo saya Pendidikan ners,kalo perawat yang ada mereka kebanyakan masih d3 keperawatan...

“...Tim A dan Tim B di dalam tim tersebut ada 2 perawat penanggung jawab yang berpendidikan S. Kep. Ners juga dan di situ eee dia bertanggung jawab

\section{Pengelolaan Keuangan}

Aturan pemerintah dalam pemberian atau pengelolaan keuangan petugas Covid 19 diharapkan mampu memberikan motivasi bagi para medis dalam melayani pasien serta membantu negara untuk bebas dari wabah virus Covid 19. Insentif mampu memberikan motivasi yang tinggi untuk para pekerja dengan kebijakan insentif yang diberikan oleh negara Indonesia untuk para tim medis dalam melayani masyarakat terpapar Covid 19 harus jelas besaran yang akan diterimanya, begitu pula kerja yang harus dilakukan oleh tim medis saat pandemik Covid 19.

Menurut Harisah 2020 Kebijakan pemerintah Indonesia dalam memberikan insentif Covid 19 bagi para tim medis yang melayani masyarakat terpapar virus corona. Pemberian insentif ini juga sebagai bentuk apresiasi pemerintah atas kesediaan para medis dalam membantu masyarakat terpapar virus Covid 19, yang pada hakikatnya para medis dihadapkan dengan resiko yang sangat tinggi. Dengan demikian besaran insentif yang didapatkan para medis sesuai tingkatan resiko yang dihadapi. Sesuai dengan hasil penelitian ini dimana beberapa partisipan mengatakan semua petugas Covid 19 baik relawan maupun ASN mendapat intensif berupa uang 7,5 juta perbulan dan di berlakukan dengan perhitungan hari kerja 22 hari.

“...iya saya tau”sebagai kepala ruangan saya mengelola data data untuk aprahkan isentif berupa uang 7,5 juta perbulan untuk perawat di ruang Covid 19 perbulan...

"...Gini waktu kita mau mulai membuka ruangan COVID 19dan kita ada info bahwa eee pasien perawat maupun organik maupun relawannya ASNnya itu kita memang di infokan bahwa kita mendapat insentif dari Kemenkes yaitu 1 orang Rp7.500.000

Menurut penelitian yang dilakukan oleh Song Y., et al tahun 2020 tentang "Optimization of the intravenous infusion workflow in the isolation ward for patients with coronavirus disease 2019" Dimasa pandemi seorang kepala ruangan harus memiliki perhitungan yang matang tentang pengelolaan keuangan ruangan. Dimana perhitungan yang tepat dapat membantu dalam proses pelayanan keperawatan bagi klien maupun bagi tenaga kesehatan. Sesuai dengan hasil penelitian ini dimana beberapa partisipan mengatakan untuk pengelolaan intensif nakes dikelola oleh kepala ruangan di sesuaikan dengan hari kerja dan kebijakan lainya dari rumah sakit jika ada pemasukan jasa insentif lainya. 
“...Amm..,untuk saat ini yang memegang pengelolaannya keuangan itu saya segagai kepala ruangan dan ,sebagai koordinator dalam pelayanan amprhan ruangan tersebut.

"..Nggak ada, makanya itu tadi kan ada yang organik ada yang ASNnya yang relawan. Relawan kan ada yang pernah melakukannya paling nggak ada di pengalamannya dia ya

Beberapa partisipan pada penelitian ini juga mengatakan dalam mengelola keuangan intensif nakes Covid 19 ada petugas khusus yang mengatur proses amprahan intensif nakes dan intensif sudah si atur sesuai dengan aturan yang berlaku ini sudah sejalan dengan aturan pemberlakuan intensif nakes yang sudah di atur selama pandemik Covid 19 pada setiap kepala ruangan yang mengelola dan menghintung intensif nakes.

“...Kita nggak mungkin juga karena kita sebagai pegawai negeri sipil kita juga punya gaji sudah yang kita punya insentif yang lain tapi kalau bisa sih disesuaikanlah dengan ininya apa ya nggak pukul rata lah

“...Ohh dalam bentuk keuangan. Mungkin ada jasa nya jadi ada pendapatan yang lain dari bentuk insetif itu.

3. Ketersedian Alat habis pakai.

Berdasarkan tipe rumah sakit perencanaan kesedian material tentu berbeda beda sumber dana yang digunakan dalam operasional rumah sakit termasuk pembelian alat medis yaitu berasal dari biaya berobat pasien terutama saat lonjakan pasien saat pandemi Covid 19. Dalam hal pembelian alat medis, pihak rumah sakit akan melakukan perhitungan tentang efektifitas dari pembelian alat medis tersebut untuk perawatan pasien Covid 19. Berapa harga yg dikeluarkan untuk suatu alat saat pembelian alat harus berbanding lurus dengan pendapatan yang didapat dari pasien saat penggunaan alat tersebut dan selalu ada dalam kesedian material di suatu rrumah sakit Proses perencanaan kesedian alat medis dimulai dari sosialisasi kebijakan oleh setiap kepala ruangan Selanjutnya tenaga medis selaku pengguna alat mengajukan permintaan alat medis dan pengunaannya dilapangan sesuai dengan kebutuhan saat pandemik Covid 19. Berdasarkan Peraturan Menteri Kesehatan Republik Indonesia Nomor 72 Tahun 2016 tentang standar pelayanan kefarmasian di rumah sakit bahwa perencanaan kebutuhan merupakan kegiatan untuk menentukan jumlah dan periode pengadaan sediaan farmasi, alat kesehatan dan barang habis pakai sesuai dengan kegiatan pemilihan untuk menjamin terpenuhinya kriteria tepat jenis, tepat jumlah, tepat waktu, dan efisien Perencanaan dilakukan untuk menghindari kekosongan persediaan dengan menggunakan metode yang dapat dipertanggungjawabkan dan dasar-dasar perencanaan yang telah ditentukan antara lain konsumsi, epidemiologi, dan disesuaikan dengan anggaran yang tersedia. Pedoman perencanaan harus mempertimbangkan penetapan prioritas, sisa persediaan, dan data pemakaian periode lalu..

Menurut (Jum \& Dia, 2021) dalam tata kelola manajemen keperawatan klinis di era Covid 19 ketersedian alat habis pakai sangatlah penting penting dan juga APD 
termasuk masker sarung tangan jubah dan pelindung mata, harus di prioritaskan bagi tenaga kesehatan dan orang lain yang merawat pasien Covid 19 dengan demikian untuk mengurangi kendala tersebut wajib dilakukan inventarisasi alat habis pakai dan juga ruang khusus penyimpanan barang habis pakai saat pandemi dan beberapa partisipan dalam penelitian ini mengatakan untuk mempermudah kita ada grup untuk mengelola barang habis pakai dan inventaris alat jadi agak mudah dan di ruangan pun ada tempat penyimpanan inventaris barang dan ada catatan khusus.

“...yang pasti untuk materialnya ada catatan khusus untuk alat invetaris ruangan kalau misalkan ada kerusakan material, kalau ada masalah segera dilaporkan kepada yang berwenang ..."

„....Kita kan punya bagian nama nya untuk perbaikan sarana, , nanti petugasnya akan langsung datang untuk memperbaiki.

Beberapa partisipan pada penelitian ini juga mengatakan dalam mengelola inventaris barang kita ada petugas khusus yang mencatat kebutuhan barang yang diperlukan selama pandemik Covid 19 ini dan juga kita di beri pelatihan khusus jika ada alat atau inventaris barang yang memerlukan perlakuan khusus seperti penyimpanan dan pengunaan sesuai dengan kebutuhan di ruangan.

“...Untuk alat-alat seperti tensimeter untuk eeee termogram segala, status form mungkin kita ga bisa satu pasien 1 alat-alat yang lain 1 alat engga. Cuman, ini ada dua tim dibagi dengan posisi kamar tidurnya di ruangan kita bagi untuk alatalat

„, “...Eee kalau perlakuan khusus kita kan kayak sentral ya ada tabung, paling kita tabung itu yang kita cuci supaya kan misalanya kalau ada jamur kotorkotoran itu ya itu aja sih sebenarnya

4. Ketersedian Alat Medis.

Rumah sakit merupakan bagian integral dalam pelayanan kesehatan. Agar Rumah Sakit dapat memberikan pelayanan yang berkualitas selama pandemik Covid 19, Rumah Sakit harus didukung oleh sumber daya yang memadai baik deri segi kualitas maupun kuantitas. Sumber daya yang dimaksud adalah Sumber Daya Manusia (SDM), alat, sarana dan prasarana untuk mendukung ruangan yang merawat pasien Covid 19. Selain itu, Rumah Sakit dituntut untuk berusaha secara optimal menjaga kesiapan alat medik, sarana dan prasarana penunjang dengan baik dan konsisten Peralatan medik sangat membutuhkan pemeliharaan dan pengawasan untuk menghindari kegagalan fungsi alat medik, kesalahan dalam mendiagnosa dan dapat menghambat pemberian pelayanan kesehatan pada pasien. Sehingga ketepatan dalam pemeliharaan dan pengawasan sangat dibutuhkan oleh semua alat medik.

Peningkatan efisiensi dan efektifitas tersebut dapat dilakukan dengan beberapa cara antara lain adanya suatu guideline atau Standart Operational Procedure (SOP) dalam pemeliharan dan pemanfaatan sarana kesehatan dan alat kesehatan pendukung perawatan Covid 19, kalibrasi dan pemeliharaan rutin, pelatihan teknisi dan operator alat, sosialisasi SOP pada seluruh unit pemakai sarana dan alat kesehatan di rumah sakit yang bersangkutan serta tersedianya suku cadang. Perencanaan pengadaan 
sarana dan alat kesehatan yang matang sesuai kebutuhan baik dari sisi provider maupun konsumen akan meningkatkan pemanfaatan secara optimal.

Menurut (Ibrahim, Ngataman, \& Abrisam, 2017) limbah medis Covid 19 dan kesiapan alat medis harus dikelola dengan sesuai prosedur standar. Limbah medis Covid 19 yaitu limbah medis dari kegiatan penanganan pasien Covid 19 dan limbah B3 medis padat barang tersebut berpotensi terkontaminasi oleh zat yang bersifat infeksius atau kontak dengan pasien atau petugas di fasilitas kesehatan yang menangani pasien Covid 19 dan pengunaan beberapa alat wajib dilakuakan strilisasi agar tidak terkontaminasi beberapa partisipan dalam penelitian ini mengatakan untuk pengelolaan limbah medis di ruangan Covid 19 di bedakan dengan berbagai teknik yaitu dengan mengunakan plastic warna kuning dan pengambilan limbah medis 2 kali sehari dan dilapisi oleh dua lapis plastic kuning sehingga penanganan limbah medis pada ruangan Covid 19.

"kalau untuk semua alat disposable kami selalu membuang ketempat yang sudah di sediakan'....

"untuk pengangkutan limbah COVID 19 sehari 2 kali dan mengunakan plastik lapis 2

"limbah medis jarum suntik kami membuangnya ke safety box yang sudah di siapkan

Hasil penelitian juga di dukung Menurut M Adny Alfarel 2021 dengan disimpulkan bahwa pengelolaan sampah medis dan sampah non medis di ruang khusus perawatan Covid 19 mulai dari tahap pemilahan, pewadahan, pengangkutan, penyimpanan sementara di TPS dan pengolahan yang bekerjasama dengan pihak ke II serta sarana dan prasarana yang digunakan dalam pengelolaan sampah medis dan non medis telah sesuai dengan peraturan yang berlaku yaitu Peraturan Menteri Kesehatan Nomor 07 Tahun 2019 Tentang Kesehatan Lingkungan Rumah Sakit, Peraturan Menteri Lingkungan Hidup dan Kehutanan Nomer 56 Tahun 2015 tentang Persyaratan Teknis Pengelolaan Limbah B3 Dari Fasyankes, PP 101 Tahun 2014 Tentang Pengelolaan Limbah Bahan Berbahaya Dan Beracun beberapa partisipan dalam penelitian ini mengatakan sampah limbah medis bekas perawatan pasien Covid 19 di ruangan dipisahkan dengan keterangan infeksius dan non infeksius dan proses pengangkutan dan pengemasan di bedakan dalam proses pengelolaan bekas alat medis di ruang Covid 19.

APD yang di gunakan nakes tidak boleh langsung dilepas ada prosedur pembuangan dan pelepasan "..

"limbah medis jarum suntik kami membuangnya ke safety box yang sudah di siapkan

Dalam penelitian yang dilakukan oleh Qun Li, et al tahun 2020 tentang "Early Transmission Dynamics in Wuhan, China, of Novel Coronavirus Infected Pneumonia" Hasil dari penelitian ini terbukti bahwa transmisi antar manusia telah terjadi akibat kontak dekat. Langkah preventif harus dilakukan untuk mengurangi penularan Covid 19. penelitian ini menjelaskan bahwa faktor penyebab terpaparnya 
virus Covid 19 pada perawat diantaranya adalah alat pelindung diri yang tidak memadai (kurang), pengunaan kesiapan alat Covid 19 terkena percikan urin/feses, darah dan lendir, jatuhnya kacamata pelindung saat melakukan tindakan, percikan dahak serta kontak dengan pasien positif Covid 19 bahkan dari pasien berstatus OTG sejalan dengan penelitin ini beberapa partisipan dalam penelitian ini mengatakan alat-alat selalu dibersihkan setelah pengunaan dan di bersihkan mengunakan cara khusus agar kontaminasi kesiapan pengunaan alat Covid 19 bukan menjadi media penularan.

“...eee sampai saat ini dia pertiga bulan sekali sih, pertiga bulan sekali harusnya tapi saat ini kayaknya belum, belum ada dilakukan itu, cuman dibersihkan biasa aja di insfektan biasa"

“...Kayak sentral ya ada tabung, paling kita tabung itu yang kita cuci supaya kan misalanya kalau ada jamur kotor-kotoran itu ya itu aja sih sebenarnya

Beberapa partisipan pada penelitian ini juga mengatakan jika mengalami kerusakan alat kita kordinasikan dengan bagian alat sarana rumah sakit untuk memperbaiki alat tersebut dan cara membersihkan alat dan pemeliharaannya juga berbeda.

“...Khusus pengaduan masalah jika memang ada kerusakan atau perbaikan segera diruangan isolasi jadi kita menghubungi ee..digrub tersebut jadi mereka segera dating jadi kami tidak pernah menunggu lama

“...Kalo misalnya ada kerusakan biasanya teman-teman yang piket segera menghungi saya kemudian saya segera eee menyampaikan kebidang yang membidangi

5. Metode Pengelolaan ruangan.

Kepala ruangan sebagai manajer operasional, yang memimpin secara langsung, dalam mengelola ruangan dan seluruh sumber daya di unit perawatan untuk menghasilkan pelayanan yang bermutu, dan dituntut untuk menjadi motor penggerak, bagi sumber-sumber dan alat-alat dalam suatu organisasi melalui pengambilan keputusan, penentuan kebijakan dan menggerakkan orang lain untuk mencapai tujuan dimasa pandemik Covid 19.

Menurut (Jum \& Dia, 2021) Standar dari pengelolaan ruang Covid 19 harus di siapkan secara matang dan sesuai dengan aturan yang berlaku yaitu ruangan penerimaan pasien dan ruang isolasi pasien Covid 19, ruangan Nurse station, ruang untilitas kotor dan penyimpanan alat pun harus mengunakan ruangan dipisah sesuai dengan pemisahan rak rak dan juga ruang ganti petugas medis wajib di sediakan beberapa partisipan dalam penelitian ini mengatakan ada alur pemidahan pasien Covid 19 serta terdapat alur masuk dan keluar pasien Covid 19 dan juga evaluasi dari perawat untuk peletakan alat sesuai dengan tempat dan ada ruangan khusus untuk ruang ganti petugas Covid 19 jika bertugas.

Berarti pada saat ruangan itu berbentuk biasa masih bisa alat masih bisa beberapa alat masuk ke ruangan nurse station Covid 19 memang ada ruangan tersendiri untuk 
meletakan alat tersebut. Jadi ada perbedaan mengenai eee pembagian dan tata kelola ruangan Covid 19 dan non Covid 19

"...mmm sih ada diruangan sebelumnya juga ada cuman seperti ruangan sebelumnya pemakaian APD pelepasan APD itu kolaborasinya dengan PPI untuk melihat petugas pas tidak sesuai spo “...

Menurut penelitian (Utarini, 2014) tata kelola klinis adalah suatu sistem yang menjamin organisasi pemberi pelayanan kesehatan bertanggung jawab untuk terusmenerus melakukan perbaikan mutu pelayanannya dan menjamin memberikan pelayanan dengan standar yang tinggi dengan menciptakan lingkungan dimana pelayanan prima dan tata kelola ruangan akan berkembang. beberapa partisipan dalam penelitian ini mengatakan untuk metode tata kelola ruangan metode keperawatan secara fungsional tetap mengutamakan perbaikan pelayanan saja.

"...Kalau untuk metodenya untuk metode keperawatannya secara fungsional sih sama aja ya, cuman cara kita aja ya, cuma tata kelola kamarnya sendiri dan tidak boleh di tunggu keluarga.

Hal ini sejalan dengan penelitian (Karimirad, Seyedfatemi, Noghani, Dehkordi, \& Barasteh, 2018) Masa depan keperawatan yang baik membutuhkan perencanaan di tiga bidang tantangan perawatan dalam sistem kesehatan yaitu: tata kelola keperawatan, termasuk keperawatan terpusat kepada metode asuhan dan tantangan manajemen sumber daya manusia, termasuk pendidikan keperawatan yang disesuaikan dengan kebutuhan masyarakat, memberdayakan manajer keperawatan, merekrut dan mempertahankan perawat dan keperawatan khusus.

Beberapa partisipan dalam penelitian ini mengatakan kalau diruangan ada perawat penangung jawab pasien dan beberapa partisipan lagi mengatakan untuk pembagian siff pagi ada yang organik dan non organik saat merawat pasien Covid 19.

“...iya nanti memang kami bagi yang shift pagi nya memang harus ada organik, shift sorenya non organik maupun yang shift malam sebagai penanggung jawab.

“...Nah disitu untuk relawannya untuk satu sift kalau pagi memang lebih banyak di situ ada eee jumlah organiknya ada 4 relawan nya bisa 3 dan Kebetulan saya juga sebagai kepala ruangannya dan ada PJAnya.

Hal ini sejalan dengan penelitian Menurut Huber 2018 dalam penelitian Asra dewi 2021 Pada fungsi pengorganisasian berdasarkan hasil analisis, mekanisme koordinasi yang dilakukan kepala bidang keperawatan terkait monitoring dan evaluasi penyelenggaraan program kerja dilakukan melalui koordinasi dengan setiap bagian dan kepala instalasi beberapa partisipan dalam penelitian ini mengatakan untuk mengevaluasi kedisiplinan perawat dalam melepas APD Covid 19 seperti ruangan pemakaian APD Covid 19dan pelepasan APD Covid 19 itu selalu di kontrol dan evaluasi.

“...mmm sih ada diruangan sebelumnya juga ada cuman seperti ruangan sebelumnya pemakaian APD pelepasan APD itu kolaborasinya dengan PPI untuk melihat petugas pas tidak sesuai spo “ 
"...Diruangan biasa tidak perlu memakai apd lengkap,cukup memakai apron aja di ruangan biasa untuk melakukan tindakan pasien Covid

Beberapa partisipan pada penelitian ini juga mengatakan tata kelola ruangan bagaimana alur pemindahan pasien dari IGD keruangan ranap atau ruang isolasi harus sesuai dengan panduan dan pedoman dan patisipan lainya mengatakan tata kelola tim memang harus ada perawat organic dinsetiap jadwal dinas serta beberapa partisipan mengatakan belum ada SPO tata kelola pengantaran pasien. “...Untuk salah satu contohnya untuk pengantaran pasien, karena selama ini SPO nya masih belum ada. Karena selama ini kita, kita yang dari ruangan eee isolasi karena kita ruang isolasi kita yang jemput

6. Evaluasi manajemen Man, Money, Material, Machines, dan Method.

Kegiatan yang telah dilakukan perlu dievaluasi untuk menilai apakah pelaksanaan kegiatan sesuai rencana yang di harapkan pada setiap kepala ruangan yang mengelola pasien Covid 19. Oleh karena itu kepala ruangan berkewajiban untuk memberi arahan yang jelas tentang kegiatan yang akan dilakukan selama pandemik Covid 19. Dengan demikian diperlukan uraian tugas yang jelas untuk masing-masing staf dan prosedur tugas yang diperlukakan untuk melakukan kegiatan dengan memperhatikan keselamatan dan kenyamanan klien, keselamatan dan kenyamanan staf dan fasilitas dengan berdaya guna dan berhasil guna. Selain itu diperlukan juga standar penampilan kerja dan penguatan SPO dan pedoman yang diharapkan perawat mampu melakukan tugas pada garda depan penanganan pasien Covid 19. Semua ini perlu dievaluasi secara terus menerus guna dilakukan tindakan koreksi apabila ditemukan penyimpangan dari standar.

Menurut (Jum \& Dia, 2021) indikator mutu evaluasi pada masa Covid 19 adalah sistem pelayanan sebuah rumah sakit yang meliputi Man, Money, Material, Machines, dan Method ada asumsi yang menyatakan bahwa jika struktur sistem Rumah Sakit tertata dengan baik akan lebih menjamin mutu keperawatan, kualitas Rumah Sakit tentu akan menjadi baik. Pada masa pandemi Covid 19 alur dan strutur dan penerapan Man, Money, Material, Machines, dan Method harus jelas dan tegas agar pelayanan menjadi lebih baik beberapa partisipan dalam penelitian ini mengatakan penerapan Man, Money, Material, Machines, dan Method sudah berjalan baik dan mengikuti arahan dari pimpinan dan jika ada kendala kami segera melapor dan belajar lagi penerapan Man, Money, Material, Machines, dan Method sehingga tidak ada kendala dalam evaluasi Man, Money, Material, Machines, dan Method.

“...diruangan kami kadang kami lupa metode yang harus memuat Man, Money, Material, Machines, dan Method selebihnya kami usahakan menerapkan sieh sesuai dengan yang ada saja

"...eee di sesuaikan saja liat kondisi tempat kerja apa bisa dilakukan Man, Money, Material, Machines, dan Method"

Hasil penelitian menunjukkan peran kepala ruangan dalam pelaksanaan fungsi pengendalian dilakukan sebesar $74,7 \%$. Hasil penelitian ini sejalan dengan penelitian 
(Wahyuningsih, Raodhah, \& Basri, 2017) bahwa 86,1\% kepala ruangan melakukan fungsi pengendalian. Sedangkan menurut penelitian (Mutaqin, 2014) bahwa dengan pengawasan yang efektif akan memberikan hasil kerja yang berkualitas. Dengan pengawasan yang baik akan memungkinkan rencana yang telah dibuat berjalan secara efektif dan efisien. Menurut (Marquis \& Huston, 2010) menyatakan bahwa pengendalian dan cara mengatasi masalah yang efektif akan meningkatkan motivasi kerja dan hasil yang berkualitas beberapa partisipan dalam penelitian ini mengatakan kadang di ruangan kami lupa metode yang harus memuat Man, Money, Material, Machines, dan Method selebihnya kami kerjakan juga dan saat pandemik Covid 19 ini semua kegiatan Man, Money, Material, Machines, dan Method di rasa kan patisipan flexible dan sesuai dengan kebutuhan.

“...kadang proses Man, Money, Material, Machines, dan Method ada yang di dahulukan sieh di sesuaikan aja"

“...emmm kalau di ruangan saya manajemen mau simple saja gak mau ribet dalam Man, Money, Material, Machines, dan Method”

Menurut (Nursalam, 2014) juga menyatakan bahwa kepala ruangan harus secara aktif melakukan intervensi terhadap masalah supaya tidak menghambat produktifitas dan motivasi. Kepala ruangan dapat melakukan pemecahan konflik dengan memberi perhatian terhadap masalah yang ada dan memberikan peranan yang aktif. Keterlibatan kepala ruangan dalam pemecahan konflik meningkatkan motivasi bagi perawat. beberapa partisipan dalam penelitian ini mengatakan kami selalu mengadakan rapat dengan manajemen terkait cara mengatasi Man, Money, Material, Machines, dan Method saat pandemik Covid 19 dan beberapa partisipan lagi mengatakan meminta petunjuk pimpinan bagaimana cara mengatasi Man, Money, Material, Machines, dan Method di ruangan jika ada kendala dalam menangani atau kendala ruangan saat merawat pasien Covid 19.

“...ee kami selalau mngadakan rapat dengan manajemen terkait cara mengatasi hal itu

“...ee kalau ruangan saya simple saya Tanya keruangan lain tentang Man, Money, Material, Machines, dan Method ini

Beberapa partisipan pada penelitian ini juga mengatakan evaluasi terkait Man, Money, Material, Machines, dan Method di ruangan sudah tertata bagus tinggal memperbaiki saja dan beberapa partisipan juga mengatakan evaluasi penerpan Man, Money, Material, Machines, dan Method jarang terjadi masalah serius dan patisipan juga mengatakan di ruangan sudah tertata bagus dalam mengelola ruangan dan staff ruangan tinggal diperbaiki sedikit saja. Beberapa partisipan juga pada penelitian ini juga mengatakan ruangan saya belum paham jadi kami belajar lagi untuk manajemen ruangan dan partisipan juga mengatakan akan lebih belajar lagi untuk penerapan manajemen ruangan pada masa Covid 19.

“...evalusi dari penerapan Man, Money, Material, Machines, dan Method jarang terjadi masalah serius” 
“...diruangan kami sudah tertata bagus dan Man, Money, Material, Machines, dan Method sudah tertata bagus"

Kesimpulan dari seluruh tema penelitian di atas yaitu Manajemen selalu dikaitkan dengan usaha bersama yang mana merupakan suatu proses aktifitas guna mencapai sasaran atau suatu telaah yang direncanakan terlebih dahulu, untuk mencapai sasaran itu, diperlukan sejumlah sarana, fasilitas atau alat yang disebut juga sebagai unsur-unsur manajemen saat pandemik Covid 19.

Man merujuk pada sumber daya manusia yang dimiliki oleh organisasi dalam manajemen, faktor manusia adalah yang paling menentukan. Manusia yang membuat tujuan dan manusia pula yang melakukan proses untuk mencapai tujuan. Tanpa ada manusia tidak ada proses kerja, sebab pada dasarnya manusia adalah makhluk kerja. Oleh karena itu, manajemen timbul karena adanya orang- orang yang berkerja sama untuk mencapai tujuan oleh karena itu peran kepala ruangan dalam proses penerimaan pegawai baru dan penepatan tenaga pada masa pandemik Covid 19 di rasakan perlu dilakukan dan kelola dengan baik sehingga mutu dan kualitas pemeberian asuhan dalam masa pandemik Covid 19 telah sesuai sehingga unsur Money atau Uang merupakan salah satu unsur yang tidak dapat diabaikan. Uang merupakan alat tukar dan alat pengukur nilai. Besar-kecilnya hasil kegiatan dapat diukur dari jumlah uang yang beredar dalam perusahaan. Oleh karena itu uang merupakan alat (tools) yang penting untuk mencapai tujuan karena segala sesuatu harus diperhitungkan secara rasional. Hal ini akan berhubungan dengan berapa uang yang harus disediakan untuk membiayai gaji tenaga kerja dan relawan Covid 19 dan pembagian intensif nakes yang merawat pasien Covid 19 wajib dilakukan manajemen dengan baik dan alat-alat yang dibutuhkan untuk merawat pasien Covid 19 wajib dan harus dibeli serta berapa hasil yang akan dicapai dari suatu organisasi dalam pemberi layanan di masa pandemik Covid 19 ini.

Dalam penelitian di atas juga manusia yang ahli dalam bidangnya juga harus dapat menggunakan bahan/materi-materi sebagai salah satu sarana. Sebab materi dan manusia tidak dapat dipisahkan, tanpa materi tidak akan tercapai hasil yang dikehendaki dengan inventarisasi pengunaan bahan habis pakai yang di gunakan dalam merawat pasien dengan Covid 19 selama pandemi ini dan juga dalam hal ini Machine atau Mesin digunakan untuk memberi kemudahan atau menghasilkan keuntungan yang lebih besar serta menciptakan efesiensi kerja perkerjaan perawat Covid 19 semakin mudah namun harus di imbangi dengan tempat penyimpanan dan proses pemeliharaan alat dan maintenance alat selama pandemi sebagai penetapan cara pelaksanaan kerja suatu tugas dengan memberikan berbagai pertimbanganpertimbangan kepada sasaran, fasilitas-fasilitas yang tersedia dan penggunaan waktu, serta uang dan kegiatan usaha.

Perlu diingat meskipun metode baik, sedangkan orang yang melaksanakannya tidak mengerti atau tidak mempunyai pengalaman maka hasilnya tidak akan memuaskan. Dengan demikian, peranan utama dalam manajemen tetap manusianya sendiri namun proses kerja tidak akan berlangsung, sama halnya dengan rumah sakit 
jika tidak ada pasien maka proses kerja rumah sakit juga akan terhenti. Oleh sebab itu, penguasaan pasar dalam arti menyebarkan hasil produksi merupakan faktor menentukan dalam perusahaan atau rumah sakit dalam pemberi pelayanan di masa Covid 19 dan agar pasar dapat dikuasai maka kualitas dan harga barang harus sesuai dengan tingkat kepuasaan pasien.

\section{Kesimpulan}

Hasil penelitian ini menyimpulkan bahwa pengelolaan dan evaluasi kepala ruangan selama pandemic Covid 19 perlu pengelolaan sumber daya manusia, keuangan, ketersediaan bahan habis pakai, alat dan metode tata kelola ruangan menjadi perhatian khusus para manajer rumah sakit yang melakukan pemberiaan layanan kesehatan kepada pasien Covid 19 dan keluarga nya. 
Brension Relly, Yati Afiyanti, Muhammad Syafwani

\section{BIBLIOGRAFI}

Alhazzani, W., Møller, M. H., Arabi, Y. M., Loeb, M., Gong, M. N., \& Fan, E. (n.d.). \& $\mathrm{Du}$, B.(2020). Surviving Sepsis Campaign: guidelines on the management of critically ill adults with Coronavirus Disease 2019 (COVID-19). Intensive Care Medicine, 1-34.

Coulter, Mary. (2010). Manajemen Edisi Kesepuluh jilid 1.

https://coronavirus.jhu.edu/map.html. (2021).

Ibrahim, R. I., Ngataman, N., \& Abrisam, W. N. A. Wan Mohd. (2017). Forecasting the mortality rates using Lee-Carter model and Heligman-Pollard model. Journal of Physics: Conference Series, 890(1), 12128. IOP Publishing. Google Scholar

Jum, Pakpahan Panata, \& Dia, Litawati. (2021). Tata Kelola Manajemen Keperawatan Klinis Era COVID-19. Yogyakarta: Gava Media. Google Scholar

Karimirad, Mohammad Reza, Seyedfatemi, Naiemeh, Noghani, Fatemeh, Dehkordi, Ali Hasanpour, \& Barasteh, Salman. (2018). The relationship between resilience and quality of life in family caregivers of patients with mental disorders. Journal of Clinical and Diagnostic Research, 12(11), CC05-CC08.

Kurniadi, Anwar. (2013). Manajemen keperawatan dan prospektifnya: Teori, konsep dan aplikasi. Jakarta: Fakultas Kedokteran Universitas Indonesia. Google Scholar

Li, Qun, Guan, Xuhua, Wu, Peng, Wang, Xiaoye, Zhou, Lei, Tong, Yeqing, Ren, Ruiqi, Leung, Kathy S. M., Lau, Eric H. Y., \& Wong, Jessica Y. (2020). Early transmission dynamics in Wuhan, China, of novel coronavirus-infected pneumonia. New England Journal of Medicine. Google Scholar

Marquis, Bessie L., \& Huston, Carol J. (2010). Kepemimpinan dan manajemen keperawatan. EGC. Google Scholar

Mutaqin, Zezen Zaenal. (2014). Penghayat, orthodoxy and the legal politics of the state: The survival of agama djawa sunda (madraisism) in indonesia. Indonesia and the Malay World, 42(122), 1-23. Google Scholar

Nursalam, Dr. (2014). Manajemen Keperawatan" Aplikasi dalam Praktik Keperawatan Profesional. Salemba Medika. Google Scholar

Panduan Teknis Pelayanan di Rumah Sakit pada masa Kebiasaan Baru dari Kemenkes RI tahun 2020. (2020). Panduan Teknis Pelayanan di Rumah Sakit pada masa Kebiasaan Baru dari Kemenkes RI tahun 2020.

Pfefferbaum, Betty, \& North, Carol S. (2020). Mental health and the Covid-19 pandemic. New England Journal of Medicine, 383(6), 510-512. Google Scholar

Ross, Shannon E., Niebling, Bradley C., \& Heckert, Teresa M. (1999). Sources of stress 
among college students. College Student Journal, 33, 312-317. Google Scholar

Seale, Holly, Wang, Quanyi, Yang, Peng, Dwyer, Dominic E., Zhang, Yi, Wang, Xiaoli, Li, Xinyou, \& MacIntyre, C. Raina. (2012). Hospital health care workers' understanding of and attitudes toward pandemic influenza in Beijing. Asia Pacific Journal of Public Health, 24(1), 39-47. Google Scholar

Sullivan, Erin E., \& Phillips, Russell S. (2020). Sustaining primary care teams in the midst of a pandemic. Israel Journal of Health Policy Research, 9(1), 1-3. Google Scholar

Utarini, Kasyfi Hartati Hanevi Djasri Adi. (2014). Implementasi tata kelola klinis oleh komite medik di rumah sakit umum daerah di provinsi Jawa Tengah. Jurnal Manajemen Pelayanan Kesehatan, 17(1). Google Scholar

Wahyuningsih, Sri, Raodhah, Sitti, \& Basri, Syahrul. (2017). Infeksi Saluran Pernafasan Akut (ISPA) pada Balita di Wilayah Pesisir Desa Kore Kecamatan Sanggar Kabupaten Bima. HIGIENE: Jurnal Kesehatan Lingkungan, 3(2), 97-105. Google Scholar

Winasih, Rini, Nursalam, Nursalam, \& Kurniawati, Ninuk Dian. (2015). Cultural organization and quality of nursing work life on nurses performance and job satisfaction in Dr. Soetomo Hospital, Surabaya. Jurnal Ners, 10(2), 332-342. Google Scholar

Zeng, Fanmin, Sun, Xueli, Yang, Bangxiang, Shen, Hong, \& Liu, Ling. (2016). The theoretical construction of a classification of clinical somatic symptoms in psychosomatic medicine theory. PloS One, 11(8), e0161222. Google Scholar

\section{Copyright holder:}

Brension Relly, Yati Afiyanti, Muhammad Syafwani (2022)

\section{First publication right:}

Syntax Idea

This article is licensed under: 